Katarzyna Person

\title{
Filatelisty w getcie warszawskim przypadki. Historia Franza Konrada
}

W piątek 23 kwietnia 1943 r., o godzinie 10.30 rano około 3500 pracowników Werterfassung - gospodarczej agendy akcji „Reinhardt”, urzędu zajmującego się przejmowaniem i zabezpieczaniem majątku pozostawionego w getcie warszawskim przez deportowanych do Treblinki Żydów, przeszło z ul. Niskiej na Umschlagplatz, skąd zostali wywiezieni do obozów w dystrykcie lubelskim. Nic nie wiadomo o tym, by w Werterfassung prowadzono intensywną agitację wśród pracowników mającą ich przekonać do wyjazdu do obozów, tak jak się to działo w szopach Schultza czy Többensa ${ }^{2}$. Jak pisali bezpośredni świadkowie tych zdarzeń, pracownicy Werterfassung, inaczej też niż ci zatrudnieni w innych działających w getcie szczątkowym przedsiębiorstwach, nie próbowali się bronić ani ukrywać. Na Umschlagplatz mieli iść pewni, że jadący na czele pochodu SS-Obersturmführer Franz Konrad, specjalista od przejęć majątku, jest gwarantem ich bezpieczeństwa. W artykule tym podejmuję próbę odpowiedzi na pytanie, kim był ów nazista, nazywany przez kolegów z SS „królem getta”, człowiek, który w czwartym dniu powstania w getcie warszawskim, po koszmarze deportacji i pierwszych wystapieniach zbrojnych, miał wciąż, jak zapisał pamiętnikarz Ber Warm, „nieograniczony kredyt zaufania” wśród warszawskich Żydów³.

Oficjalne informacje na temat przedwojennego życiorysu Konrada, jakie można znaleźć w jego aktach osobowych SS, ograniczają się do podstawowych faktów. Franz, syn Floriana i Marii Konradów, urodził się 1 marca 1906 r. w Liesing pod Wiedniem. Katolik, z zawodu kupiec, żonaty od 1931 r., był ojcem trojga dzieci: chłopca urodzonego w 1931 r. i dwóch dziewczynek urodzonych w latach 1936 i 1939. Członek NSDAP od roku 1933 (nr partyjny 1085 499) i SS od roku 1933 (nr legitymacji 46 204) oraz Waffen SS od 6 grudnia 1939 r. Rachmistrz sztabo-

${ }^{1}$ Więcej na temat akcji „Reinhardt” zob. Akcja Reinhardt. Zagłada Żydów w Generalnym Gubernatorstwie, red. Dariusz Libionka, Warszawa: IPN, 2004. Na temat gospodarczego wymiaru akcji „Reinhardt” zob. też Stanisław Piotrowski, Misja Odyla Globocnika. Sprawozdanie o wynikach finansowych zagłady Żydów w Polsce, Warszawa: PIW, 1949.

${ }^{2}$ Zob. na przykład Archiwum Żydowskiego Instytutu Historycznego (dalej AŻIH), 301/474, Relacja Eugenii Truskier, k. 14-15.

${ }^{3}$ AŻIH, 302/188, Relacja Bera Warma, k. 2. 
wy (Stabszahlmeister) w stopniu kapitana Waffen SS, odznaczony Krzyżem Zasługi Wojennej I i II klasy oraz Krzyżem Żelaznym II klasy. Dowiadujemy się też, że przez cały okres II wojny światowej Konrad awansował tylko o dwa stopnie: z Untersturmführera SS (odpowiednik podporucznika) w roku 1939 doszedł do stopnia Hauptsturmführera (odpowiednik kapitana)w roku 1944 . Z tego opisu wyłania się więc portret co najwyżej przeciętnego oficera - nic w jego treści nie przybliża nas do odpowiedzi na pytanie, jak doszło do tego, że właśnie ten człowiek stał się „królem getta” i jako taki sądzony był w 1951 r. obok Jürgena Stroopa.

Historię życia Konrada możemy jednak poznać z jeszcze jednego, bardzo cennego, choć specyficznego źródła. On sam bowiem bardzo dokładnie opisał je dwukrotnie - po raz pierwszy, niedługo po wojnie, w 1946 r., w czasie kiedy został zatrzymany przez armię amerykańską, po raz drugi w lipcu 1951 r. podczas rozprawy przed Sądem Wojewódzkim w Warszawie. Obydwa oświadczenia są bardzo wyczerpujące, barwne i przekazują nam wiedzę nie tylko na temat biografii samego Konrada, lecz także jego powojennej autokreacji.

Opowieść o „królu getta” można dzięki temu rozpocząć od jego wczesnej młodości. Franz Konrad tak opisywał swoje wczesne lata w 1946 r.:

Za moich młodych lat pragnąłem zostać muzykiem. Wskutek stosunków materialnych życzenie to nie mogło się jednak ziścić. Po ukończeniu 6-klasowej szkoły powszechnej ojciec zabrał mnie pewnego dnia do położonej w pobliżu miejscowości jarmarcznej i tam umieścił mnie jako ucznia u pewnego kupca na naukę [...]. W ostatnim roku mojej nauki nauczyłem się grać w szachy, przystąpiłem do klubu w celu nauczenia się światowego języka pomocniczego esperanto. Dzisiaj zapomniałem już tego języka całkowicie, gdyż nie miałem sposobności do mówienia. Wtedy jednak byłem tak zaawansowany, że dumnie nosiłem odznakę esperanckiej zielonej gwiazdy na białym polu, a poza tym za pomocą materiału propagandowego rozpowszechniałem ten język ${ }^{5}$.

Po okresie terminowania u kupca Konrad znalazł pracę w Stowarzyszeniu Rozdzielczym. Na jesieni 1931 r., już jako kierownik jednej z filii Stowarzyszenia, oskarżony został o kradzież, jak twierdził w swoich zeznaniach - całkowicie bezpodstawnie. Spędził trzy miesiące w więzieniu. W 1933 r., o czym już była mowa, wstapił do NSDAP i do SS. Zwerbować miał go adwokat broniący go w sprawie o kradzież. Konrad liczył też, że krok ten pomoże mu w znalezieniu stałego zajęcia. Po krótkim okresie pracy przy budowie dróg, w lecie 1935 r., znów bezrobotny, uciekł do Niemiec, gdzie dostał się do obozu szkoleniowego SS w Weissenfeld. Od tego momentu jego kariera w tej formacji przebiegała dosyć szybko, choć nie spektakularnie. Na jesieni 1938 r. został przeniesiony już jako funkcjonariusz administracyjny SS do Austrii. W grudniu 1939 r. Konrad ukończył przyspieszony kurs dla

\footnotetext{
${ }^{4}$ Archiwum Instytutu Pamięci Narodowej (dalej AIPN), GK, 317/874, Proces Jürgena Stroopa, Franza Konrada i Hermana Höflego, Sąd Wojewódzki dla m.st. Warszawy, t. 10, Raport osobowy, SS-Untersturmführer Franz Konrad, k. 53.

${ }^{5}$ AIPN, GK, 317/874, t. 8, Oświadczenie Franza Konrada, 8 I 1946 r., k. 19-20.
} 
kierowników administracji w Berlinie. Bez wątpienia najważniejsze dla jego kariery były jednak kontakty osobiste i, jak się wydaje, duża łatwość w nawiązywaniu znajomości. Podczas pobytu w Berlinie zawarł przyjaźń między innymi z Hermannem Fegeleinem, bliskim współpracownikiem Heinricha Himmlera, członkiem najbliższego otoczenia Adolfa Hitlera i organizatorem kawalerii SS w Polsce. Od tej chwili aż do końca wojny Fegelein niejako pilotował karierę Konrada. W styczniu 1940 r. obydwaj udali się do Warszawy, gdzie Konrad objął stanowisko referenta do spraw pomieszczeń w Wydziale Rekwizycji i Zaopatrzenia (Beschlagnahme und Beschaffungswesen), urzędu, którego zadaniem była rekwizycja pomieszczeń i przedmiotów na potrzeby niemieckich władz administracyjnych i niemieckich urzędników. Na tym stanowisku zajmował się urządzaniem i przerabianiem urzędów i biur oraz mieszkań dla wysokich funkcjonariuszy SS. Z raportu osobowego Konrada wynika, że dzięki jego „zdecydowanej światopoglądowej postawie, jego spokojnemu, a zarazem stanowczemu postępowaniu oraz jego niezmordowanej pilności, potrafił wzorowo wykonywać powierzone mu zadania i prace"6. Na podstawie licznych relacji ofiar rekwizycji, tych dokonywanych z urzędu przez władze cywilne i wojskowe i tych dokonywanych na własną rękę przez członków SS, można wnioskować, że Konrad z całego procederu odnosił też duże korzyści materialne. Nie udało mi się jednak natrafić na zeznania nikogo, kto bezpośrednio stał się w tym okresie ofiarą jego działalności. Jedynym źródłem na temat tego etapu jego kariery pozostają więc zeznania samego Konrada, które, podobnie jak te dotyczące młodości, są bardzo barwne i prawdopodobnie w dużym stopniu odbiegają od rzeczywistości. Zeznając w 1946 r., Franz Konrad opowiadał:

Jako człowiek urodzony w górach, bez przygotowania, nie znając dużego miasta, nie mogłem się pogodzić z myślą odebrania czegokolwiek komuś, choćby miał być żydowskiej rasy.

Byłem oburzony i wszystko we mnie sprzeciwiało siętemu. Prze[d]łożyłem to Franciszkowi Friedrichowi i prosiłem, aby zadanie to powierzono komu innemu. Otrzymałem odpowiedź, że jeżeli nie zastosuję się do rozkazu, zostanę pociągnięty do odpowiedzialności za niesubordynację, ponadto zostałem wyszydzony i napiętnowany jako tchórz, i wyśmiany przez kolegów, że jako człowiek SS nie mam odwagi odebrania czegokolwiek Żydom. Przed tym jako przynależny do SS nie zajmowałem się zagadnieniem żydowskiej rasy. Nie znałem nigdy Żydów jako masy, z wyjątkiem jednego z nich, którego poznałem podczas okresu nauki i znałem jako człowieka pracowitego i bardzo pilnego. Gdy przeżywałem w moich myślach otrzymany rozkaz, doszedłem do przekonania, że niesprawiedliwość wyrządzona drugiemu zemści się zawsze. Była to moja myśl przewodnia podczas wykonywania późniejszych czynności i wszystkie rozkazy wypełniałem z punktu widzenia ludzkiego i mojego sumienia?

\footnotetext{
${ }^{6}$ Ibidem, t. 10, Raport osobowy, SS-Untersturmführer Franz Konrad, k. 53.

${ }^{7}$ Ibidem, t. 8, Oświadczenie Konrada, k. 27.
} 
Podczas rozprawy przed warszawskim sądem twierdził ponadto, że meble z mieszkań żydowskich brał tylko w okresie przejściowym, przez trzy tygodnie, potem starał się je zdobywać przez urząd gubernatora dystryktu ze składów znajdujących się przy ul. Senatorskiej ${ }^{8}$. Według jego własnej wersji, Konrad miał przy konfiskacie wybierać mieszkania opuszczone, w których lokalizowaniu mieli mu pomagać żydowscy pomocnicy. Jak zapewniał, jego postępowanie sprawiło, iż rodziny żydowskie miały zapraszać go do siebie „nie ze strachu, że im coś odbiorę, lecz z czysto osobistego zrozumienia szukając ze mną kontaktu”.

Latem 1941 r. Fegelein objął dowództwo 8. Dywizji Kawalerii SS „Florian Geyer” i wysłany został na Wschód. Wraz z nim Warszawę opuścił jego protegowany Franz Konrad. Kawaleria SS zapisała się w historii frontu wschodniego udziałem w masakrach cywilów i ludności żydowskiej, nie ma jednak podstaw, by twierdzić, że Konrad, który jako urzędnik administracyjny pozostawał na zapleczu, brał w nich udział. On sam potwierdzał po wojnie, że był dobrze poinformowany o działalności jednostki, lecz osobiście zajmował się wyłącznie organizacją transportu prowiantu dla żołnierzy na froncie ${ }^{10}$. Latem 1942 r. Konrad został oddelegowany do zorganizowania mających powstać na Kaukazie urzędów remontowych broni SS. Z powodu zmiany sytuacji na froncie wschodnim od planu jednak odstapiono. Zamiast na Kaukaz, wezwany został do Warszawy.

Konrad pojawił się ponownie w Warszawie prawdopodobnie pod koniec czerwca lub w lipcu 1942 r. Jego pierwsze działania w stolicy nie są do końca jasne. On sam twierdził, że z polecenia Fegeleina miał się zainteresować możliwościami zarobku w getcie warszawskim i wykorzystania kredytów państwowych przekazywanych przez Trzecią Rzeszę dla tych firm, które na bazie żydowskiej siły roboczej prowadziły produkcję zbrojeniową ${ }^{11}$. Konrad nie był oczywiście jedynym, który w tym okresie szukał pieniędzy w getcie. Jak wiadomo, już od połowy 1941 r. działały tam i rozwijały się duże przedsiębiorstwa niemieckie zrzeszone w Deutsche Firmengemeinschaft Warschau GmbH. Dodatkowo w tym samym czasie, w którym pojawił się tam Konrad, w połowie 1942 r., w dzielnicy żydowskiej zakładano liczne nowe firmy. Tatiana Brustin-Berenstein wymienia wśród nich oprócz Konrada na przykład Karola Heinza Millera, firmę papierniczą A-Ha-Ge Zimmermann czy firmę Gustaw Siegmund ${ }^{12}$.

Pierwszym celem Konrada stało się przejęcie przedsiębiorstwa Kohna i Hellera firmy zrzeszającej kilkanaście mniejszych przedsiębiorstw, głównie produkujących na potrzeby wojska. Jak wspominała w powojennym śledztwie pracująca w biurze Kohna i Hellera Karolina Marek, Konrad przystapił do negocjacji w sprawie przejęcia firmy jeszcze przed rozpoczęciem deportacji w końcu lipca 1942 r. ${ }^{13}$ Do przejęcia

${ }^{8}$ Ibidem, t. 1, Protokół rozprawy głównej w dniu 18 VII 1951 r., k. 12.

${ }^{9}$ Ibidem, t. 8, Oświadczenie Konrada, k. 30.

${ }^{10}$ Ibidem, k. 35.

${ }^{11}$ AIPN, GK, 317/874, t. 1, Protokół rozprawy głównej w dniu 18 VII 1951 r., k. 13.

${ }^{12}$ Tatiana Brustin-Berenstein, Rola przedsiębiorców niemieckich w eksterminacji ludności żydowskiej w getcie warszawskim „BŻIH” 1955, nr 1-2 (13-14), s. 191.

${ }^{13}$ AIPN, GK, 317/874, t. 8, Zeznanie świadka Karoliny Marek, k. 133. 
początkowo jednak nie doszło, według słów Konrada z powodu zdecydowanego sprzeciwu Ferdinanda von Sammern-Frankenegga, dowódcy SS i policji w dystrykcie warszawskim ${ }^{14}$. Konradowi udało się przechwycić firmę dopiero później (być może w końcu sierpnia lub we wrześniu 1942 r.), po śmierci jej właścicieli 7 sierpnia 1942 r. Kolejne, tym razem zakończone sukcesem, przedsięwzięcie Konrad podjął wspólnie z przedsiębiorcą i właścicielem szopów Waltherem Többensem ${ }^{15}$. Przy pomocy agentów-naganiaczy wyszukiwali oni właścicieli przedsiębiorstw żydowskich, które za odpowiednio wysokie łapówki przyłączano do tzw. Exportabteilung przy firmie Többensa, właścicielom zaś obiecywano bezpieczeństwo w czasie deportacji. Jak czytamy w akcie oskarżenia z procesu w 1951 r., pomimo zapewnień Konrada dołączenie do „Exportabteilung” nie gwarantowało bezpieczeństwa - wielu tych, którzy płacili za dołączenie się do firmy, było wywożonych już następnego dnia ${ }^{16}$. Wspólna działalność Konrada i Többensa trwała do września 1942 r., kiedy większość właścicieli przedsiębiorstw wraz z rodzinami została wywieziona do Treblinki. Sam Konrad twierdził w czasie procesu, że do stworzenia tego przedsięwzięcia nigdy nie doszło ${ }^{17}$.

W tym samym czasie poza prowadzeniem własnych interesów Konrad rozpoczął współpracę z Walterem Geiplem, kierownikiem Werterfassung - nowo powstałego urzędu przejmowania mienia. Podobne do warszawskiego Werterfassung brygady zbierające pozostałe po wywiezionych dobra materialne (Aufräumungskommando) organizowane były we wszystkich większych gettach likwidowanych w ramach akcji „Reinhardt”. Oficjalnie warszawski Werterfassung połączył się ze sztabem akcji „Reinhardt” w styczniu 1943 r., kiedy urząd został wcielony do zakładanej wówczas firmy Osti (Ostindustrie - Przemysł Ziem Wschodnich), spółki podporządkowanej SS-Wirtschafts- und Verwaltungshauptamt. Celem Osti było tworzenie w żydowskich obozach pracy w dystrykcie lubelskim przedsiębiorstw produkcyjnych wykorzystujących pracę więźniów. Z tego względu należało przenieść zakłady warszawskie wraz z kilkunastoma tysiącami Żydów do obozów w dystrykcie lubelskim. Przygotowania do likwidacji getta zostały jednak przerwane przez akcję styczniową 1943 r. Transporty z Warszawy dotarły więc do obozów dystryktu lubelskiego dopiero w drugiej połowie mar$\mathrm{ca}^{18}$. To opóźnienie zostało w stu procentach wykorzystane przez Konrada, który od września 1942 r. przejął po odwołanym ze stanowiska Geiplu kierownictwo Werterfassung.

${ }^{14}$ Ibidem, t. 1, Protokół rozprawy głównej w dniu 18 VII 1951 r., k. 13.

${ }^{15}$ Zob. Brustin-Berenstein, Rola przedsiębiorców niemieckich..., k. 189.

${ }^{16}$ AIPN, GK, 317/874, t. 1, Protokół rozprawy głównej w dniu 18 VII 1951 r., k. 18.

${ }^{17}$ Ibidem, k. 13.

${ }^{18}$ Szczegółowe informacje na temat transportów Żydów z Warszawy do obozu koncentracyjnego na Majdanku i obozów pracy w dystrykcie lubelskim znajdują się w artykule Aliny Skibińskiej 1943: z warszawskiego getta do obozów na Lubelszczyźnie w relacjach żydowskich [w:] Erntefest, 3-4 listopada 1943. Zapomniany epizod Zagłady, red. Wojciech Lenarczyk, Dariusz Libionka, Lublin: Państwowe Muzeum na Majdanku, 2009, s. 153-182. 
Podstawową działalnością Werterfassung było zabieranie z opróżnionych w wyniku deportacji i zmian granic getta domów najbardziej wartościowych przedmiotów i surowców, które następnie składowano w pustych blokach w getcie. W swoich zeznaniach z 1946 r. Konrad wymienił 15 znajdujących się w getcie składów, co warto tu przytoczyć w celu ukazania pełnej skali jego działalności:

Skład I. Mieścił się w nim mój urząd z żydowskimi urzędnikami, 1 wielka stolarnia, która wyrabiała przeważnie skrzynki do radia i radia (typ pojedynczy). Były tam również składane, naprawiane, politurowane itp. meble przeznaczone dla urzędów. 1 skład na ok. 200 fortepianów i pianin, instrumentów muzycznych i odpowiednich części.

Skład futer i skór, które zostały oddane do Centrali Państwowej w Lipsku, wartości 1,2 mln marek.

Dywany i kilimy wartości tysięcy marek.

Rzadka literatura żydowska.

Obrazy olejne i ich naprawa.

Zegarki i warsztaty naprawy z ogromnymi składami części wymiennych.

Znaczki pocztowe.

Skład II. Skład na wyroby włókiennicze, ubrania, srebro, porcelanę, towary łokciowe, pasmanterię, guziki (jedna firma zrobiła ofertę na te guziki w wysokości 100000 marek).

Skład III. Chemikalia, farby, artykuły drogeryjne, lekarstwa, skóra, konopie. Skład IV. Meble, wartościowe kielichy i przedmioty sztuki (van Delft).

Skład V. Bielizna - wybrana bielizna była czyszczona i oddawana do składu II. Skład VI. Papier, urządzenia biurowe i zabawki.

Skład VII. Artykuły kosmetyczne, pasta do zębów, kremy do butów, lepy na muchy, czapki spadochronowe, obuwie z łyka.

Skład VIII. Składy mebli, włos koński i trawa morska.

Skład IX. Meble i skład książek.

Skład X. Meble i skład książek.

Skład XI. Poduszki.

Skład XII. Wyroby z bakelitu.

Skład XIII. Odlewnia metali.

Skład XIV. Warsztaty metalowe.

Skład XV. Introligatornie, drukarnie, składy książek, składy maszyn ${ }^{19}$.

W swoim zeznaniu Konrad nie podawał adresów poszczególnych składów. Wiemy jednak, że znaczna ich część znajdowała się w kompleksie budynków przy ul. Niskiej, gdzie zorganizował też zakwaterowanie dla pracowników urzędu. Każdy z magazynów miał swój szyld z numerem i wyszczególnieniem prowadzonego działu² ${ }^{20}$

Na składy przeznaczono wszystkie większe powierzchnie w getcie, w tym kościół katolicki św. Augustyna na Nowolipkach i budynek Wielkiej Synagogi przy ul. Tłomackie, w którym zorganizowano największy w getcie magazyn. Zgromadzone w budynku synagogi meble po uprzednim zamieszczeniu ogłoszeń w prasie

\footnotetext{
${ }^{19}$ AIPN, GK, 317/874, t. 8, Oświadczenie Konrada, k. 55-56.

${ }^{20}$ AŻIH, 302/27, Samuel Puterman, „Getto warszawskie”, k. 254.
} 
wyprzedawano polskiej ludności Warszawy. Zatrudniony jako strażnik magazynów Werterfassung Samuel Puterman pisał, że meble z synagogi sprzedawano w nim na sztuki, całe komplety, a nawet zawartość całego wypełnionego gmachu na raz, taksując wartość zgromadzonych w nim mebli na oko ${ }^{21}$.

Choć meble na Tłomackie dostarczał Werterfassung, sama sprzedaż organizowana była przez Zarząd Komisaryczny Zabezpieczonych Nieruchomości. Opisując na przykładzie tego magazynu działanie Werterfassung, Franz Konrad relacjonował:

Wszystko nadające się do użytku, włącznie z papierem i łachmanami, było zwożone za pomocą furmanek (ok. 100 koni) do przewidzianych składów.

Dalej zmobilizowałem furmanki konne z Urzędu Cywilnego Dróg i Komunikacji sp. z o.o., gdzie otrzymywałem za zapłatą 50 furmanek 1-2-konnych dziennie. Furmanki te miały za zadanie przewożenie mebli i innych przedmiotów pozostałych w pojedynczych mieszkaniach pod eskortą żydowskiej służby porządkowej do synagogi wyłączonej w tym czasie z getta warszawskiego [...]. Rozliczanie odbywało się przez wpłatę dochodu na rzecz SS i Policji Dystryktu Warszawskiego, Oddział Ujęcia Przedmiotów Wartościowych, do Banku Emisyjnego, filia Warszawa, w Polsce. [...] Odbiór wynosił przy zamknięciu rachunku ok. 5000 marek niemieckich. Pozostałe przejęte przedmioty wartościowe były składane do przewidzianych i już wymienionych budynków fabrycznych oraz bloków mieszkalnych ${ }^{22}$.

W getcie szczątkowym synagoga na Tłomackiem częściowo przejęła więc funkcję odgrywaną przed deportacjami przez sądy na Lesznie, gdyż spotykali się tam w sprawach handlowych i osobistych Polacy i żydowscy pracownicy Werterfassung ${ }^{23}$.

Praca Werterfassung nieustannie się rozrastała, na początku grudnia 1942 r. firma zatrudniała 3200 osób, miesiąc później miała już 3700 pracowników²4. Pracowali oni nie tylko przy wynoszeniu rzeczy z mieszkań, lecz także w sortowniach, w pralniach, szwalniach i magazynach. Do pomocy Werterfassung ściągano też strażników w szopach, tzw. werkschutzów i członków Żydowskiej Służby Porządkowej. Zatrudnienie tej ostatniej grupy doprowadziło w końcu 1942 r. do ostrego konfliktu Konrada z jej ówczesnym kierownikiem Józefem Szeryńskim. Szeryński miał się sprzeciwiać zatrudnieniu 150 funkcjonariuszy SP jako tragarzy, podnosząc, że i tak pracują już po 15 godzin na dobę. Jak pisze w swym pamiętniku funkcjonariusz SP Samuel Puterman: „Po kilkudniowych pertraktacjach [Szeryński] uzyskał tylko skreślenie nocnych patroli, których zadaniem było pilnowanie domów przed wkradającym się przez mur aryjczykami”25. Sam Konrad również opowiadał w czasie procesu o „dzikim plądrowaniu przez ludność polską, która

\footnotetext{
${ }^{21}$ Ibidem, k. 256.

${ }^{22}$ AIPN, GK, 317/874, t. 8, Oświadczenie Konrada, k. 54.

${ }^{23}$ Rachela Auerbach, Werterfassung, „Nasze Słowo” 1949, nr 3-4, s. 11.

${ }^{24}$ Brustin-Berenstein, Rola przedsiębiorców niemieckich..., s. 198.

${ }^{25}$ AŻIH, 302/27, Samuel Puterman, „Getto warszawskie”, k. 256.
} 
wtargnęła do opustoszałych domów tak gwałtownie, że zdarzały się nawet wypadki śmierci" ${ }^{26}$. Puterman podaje, że w rezultacie rozwinięcia działalności urzędu do pracy w Werterfassung oprócz stałych robotników dwa razy w tygodniu zobowiązane były żony funkcjonariuszy Służby Porządkowej i urzędników gminy²7. Do pracy rekrutowano ponadto tych, którzy na terenie getta przebywali nielegalnie, bez przydziału pracy ${ }^{28}$.

W swej działalności Konrad odnosił na tyle spektakularne sukcesy, że na początku 1943 r. Odilo Globocnik, dowódca SS i policji w dystrykcie lubelskim kierujący akcją „Reinhardt”, zaprosił do inspekcji jego warsztatów Heinricha Himmlera. Demonstracja ta miała na celu udowodnienie wartości Żydów warszawskich, by móc ich wykorzystać jako siłę roboczą na rzecz przemysłu wojennego Trzeciej Rzeszy. Znakomicie działające zakłady miały być wsparciem dla planów produktywizacji Żydów i utrzymania obozów pracy przymusowej. Samemu Konradowi podkreślana we wszystkich zeznaniach wizyta Himmlera wydawała się ukoronowaniem jego kariery. Tak samo postrzegali ją zarówno mieszkańcy getta, jak i niemiecka administracja. W relacji tej wizyty zamieszczonej w „Wiadomościach” - konspiracyjnym biuletynie redagowanym w kręgu „Oneg Szabat” - donoszono: „W getcie zwiedził Himmler magazyny Werterfassung przy ul. Dzielnej 35 i Dzielnej 69 (niejedyne zbiornice zagrabionego mienia żydowskiego). Nie zainteresował się shopami, fabrykami i warsztatami Żydów, lecz tylko swoim dziełem - Werterfassung"29. Sam Himmler, zadowolony z postawy Konrada, opisał go w raporcie z wizyty jako człowieka „bardzo miłego i sprawiającego doskonałe wrażenie” ${ }^{30}$. W rezultacie von Sammern-Frankenegg zaprosił Konrada i innych pracowników urzędu tego samego wieczoru na wódkę¹.

„Jedyny ratunek: «szabrowanie», tj. sprzedawanie rzeczy po wysiedlonych” - napisał Emanuel Ringelblum w październiku $1942 \mathrm{r} .{ }^{32}$ Nie jest przesadą stwierdzenie, że getto szczątkowe żyło $\mathrm{z}$ Werterfassung. Rzeczy po wysiedlonych sprzedawano innym Żydom, Polakom przychodzącym po nie specjalnie do getta czy woźnicom zatrudnionym przy ich transporcie ${ }^{33}$. Wydaje się, że większość pracowników urzędu

${ }^{26}$ AIPN, GK, 371/874, t. 8, Oświadczenie Konrada, k. 48.

${ }^{27}$ AŻIH, 302/27, Samuel Puterman, „Getto warszawskie”, k. 254.

${ }^{28}$ W Archiwum Ringelbluma znajduje się na przykład obwieszczenie Wydziału Pracy i Komisji Pracy Rady Żydowskiej w Warszawie z 20 IX 1942 r., zawierające wezwanie wszystkich niezatrudnionych do rejestracji do pracy w Werterfassung (AŻIH, Ring. II 73).

${ }^{29}$ Szymon Datner, „Wiadomości” - podziemny organ prasowy w getcie warszawskim z okresu po „wielkim wysiedleniu”, „Biuletyn ŻIH” 1970, nr 76, s. 79.

${ }^{30}$ Eksterminacja Żydów na ziemiach polskich w okresie okupacji hitlerowskiej. Zbiór dokumentów, zebrali i oprac. Tatiana Berenstein, Artur Eisenbach, Adam Rutkowski, Warszawa: ŻIH, 1957, s. 182 .

${ }^{31}$ AIPN, GK, 317/874, t. 1, Protokół rozprawy głównej w dniu 18 VII 1951 r., k. 39.

${ }^{32}$ Emanuel Ringelblum, Kronika getta warszawskiego, oprac. Adam Rutkowski, Warszawa: Czytelnik, 1983, s. 411.

${ }^{33}$ AŻIH, 302/139, Natan Żelechower, „Pamiętnik”, k. 21. 
zaangażowana była w sprzedaż rekwirowanego majątku i do pewnego stopnia ta sytuacja, pozwalająca utrzymać robotników przy życiu, spotykała się z akceptacją władz Werterfassung. Rzeczy zabierano powszechnie, czasem dzieląc się nimi z nadzorcami niemieckimi ${ }^{34}$. Pamiętnikarz Karol Rotgeber zapisał, że Niemcy sprzedawali czasem zawartość całego domu Żydom za ryczałt 10 000-13 000 zł․ Atmosferę panującą w Werterfassung Rachela Auerbach, opisująca wspólne gotowanie pracowników w kuchniach opuszczonych mieszkań, nazywała wręcz „cmentarną idyllą”36. Wydaje się, że w porównaniu z katorżniczym reżimem obowiązującym w wielu szopach praca w Werterfassung mogła rzeczywiście wydawać się relatywnie atrakcyjna.

Jednocześnie jednak, o czym nie można zapominać, istotą pracy zatrudnionych w Werterfassung było przejmowanie przedmiotów po zamordowanych sąsiadach, przyjaciołach czy członkach rodziny. Zatrudniony tam Natan Żelechower pisał: „Mieszkania żyły jeszcze, my przyszliśmy je zabijać, przychodziliśmy rozerwać w strzępy tę złudę życia budowanego w serdecznym nastroju rodzinnego szczęścia. Nie umiałem zabrać się do tego, kiedy pierwszy raz musiałem wyrwać z ram obraz jakiegoś Żyda i zniszczyć, miałem uczucie[, że] popełniam mord”37. Podobne odczucia są powszechne również we wspomnieniach innych zaangażowanych $\mathrm{w}$ przejmowanie mienia.

Zatrudnieni w Werterfassung mieszkańcy getta radzili sobie z problemami moralnymi zazwyczaj przez sabotaż, zjawisko wymieniane przez większość tych, którzy byli w tej organizacji zatrudnieni lub mieli z nią kontakt. Polegał on przede wszystkim na niszczeniu wartościowych przedmiotów - obrazów czy porcelany, często przy zupełnym braku reakcji niemieckich nadzorców ${ }^{38}$. Sabotaż w takiej formie był zresztą uprawiany również przed wejściem Werterfassung do domów. Cytując znowu Rachelę Auerbach: „Rąbanie mebli własnych czy bezpańskich - aby się nie dostały Werterfassung - należało do najlepszego tonu"39.

Nie ulega wątpliwości, że Werterfassung powszechnie uważane było za najbezpieczniejsze miejsce pracy w getcie szczątkowym i jako takie było najbardziej pożądane. Rachela Auerbach wspominała:

W żadnej gałęzi niemieckiej produkcji Żydzi nie czuli się tak bezpieczni i potrzebni, tak - długowieczni, jak właśnie w Werterfassung. „Życiowe numery” ani jednego „szopu” - nawet Schultza i Többensa - nie osiągnęły tak wysokiego kursu, jak numery Werterfassung. I nigdzie też nie panowała atmosfera takiego bezpieczeństwa, jak w siedzibie tej placówki na ul. Niskiej, pod „opiekuńczym skrzydłem” jej szefa, sprytnego geszefciarza SS Sturmführera Konrada. [...] Na Niskiej jeszcze nawet po akcji styczniowej ludzie utrzymy-

\footnotetext{
${ }^{34}$ Auerbach, Werterfassung, s. 11.

${ }^{35}$ AŻIH, 302/48, Karol Rotgeber, „Pamiętnik”, k. 134.

${ }^{36}$ Auerbach, Werterfassung, s. 11.

${ }^{37}$ AŻIH, 302/139, Natan Żelechower, „Pamiętnik”, k. 21.

${ }^{38}$ Auerbach, Werterfassung, s. 11

${ }^{39}$ Rachela Auerbach, Po „Akcji”, „Nasze Słowo” 1949, nr 5-6, s. 10.
} 
wali we względnym porządku mieszkania, na noc rozbierali się do spania. Zdawało im się, że przeżyją wszystkich. Oni i pracownicy zakładów pogrzebowych Pinkierta - uprzątacze trupów i uprzątacze rzeczy martwych, czuli się ludźmi najbardziej „życiotrwałymi” w getcie warszawskim ${ }^{40}$.

Do tego poczucia bezpieczeństwa przyczynił się też na pewno sam Konrad. W getcie krążyła opinia o Konradzie jako łapowniku i człowieku przekupnym, ale zasadniczo, w odróżnieniu od innych hitlerowców, niegroźnym. Najbardziej znana była jego pasja filatelistyczna, o której w 1951 r. wspominał prawie każdy z zeznających podczas jego procesu świadków. Jeden z nich tak o niej opowiadał: „O Konradzie nic nie wiem poza tym, że lubił zbierać znaczki. Słyszałem od tych ludzi, z którymi się stykał, że lubi zbierać znaczki, nawet do tego stopnia, że gdyby mu piękną kolekcję znaczków pokazać, poszedłby za nią do Berlina, nie widziałby świata poza nią"41. Inny twierdził, że Konrad miał mieć żydowskiego asystenta zajmującego się wyłącznie wyszukiwaniem dla niego kolekcji filatelistycznych ${ }^{42}$.

Chociaż tak go postrzegano, z zeznań Konrada jasno wynika, że był on człowiekiem mocno stąpającym po ziemi i zdawał sobie doskonale sprawę z tego, co dzieje się w getcie. Na rozprawie sądowej opisywał takie zdarzenia, jak rabunek kasy Judenratu przez członków podziemia czy zamordowanie Alfreda Nossiga, a także na przykład czy sposoby szmuglu towarów ${ }^{43}$. Informacji na ten temat miała mu dostarczać siatka żydowskich przyjaciół i informatorów. Pomimo tych, jak sam twierdził, bliskich związków, zapytany w czasie procesu o Żydów, którym ocalił życie, Konrad potrafił wymienić z nazwiska tylko „dziecko pani Brotheim. Jakiegoś Żyda, on się nazywał Unger. Jeszcze jednego, zdaje się, że Fogel się nazywał"44. Nie ulega jednak wątpliwości, że stosunki Konrada z pracującymi dla niego Żydami były bez porównania lepsze niż innych członków niemieckiej administracji getta. Co najważniejsze, w jego powojennym procesie udało się ustalić, że przynajmniej do stycznia 1943 r. Konrad znany był powszechnie w getcie jako ten, który nie zabijał Żydów. Dopiero w połowie stycznia tamtego roku pojawiła się pogłoska, że miał kazać rozstrzelać siedmiu pracowników Werterfassung zatrudnionych przy likwidacji garbarni braci Lejzorowiczów, przedsiębiorstwa uznawanego za „bezpieczne”, na którego terenie miały być ukryte znaczne kosztowności. W rewizji, prawdopodobnie zainteresowany pogłoskami, uczestniczyć miał wyjątkowo sam Konrad. Po zrewidowaniu pracowników Werfassung tych, przy których cokolwiek znaleziono, rozstrzelano. Poza tym głośnym przypadkiem nie udało się w trakcie powojennego śledztwa ustalić sytuacji, kiedy Konrad mordował lub kazał mordować, czy to w getcie szczątkowym, czy w czasie powstania kwietniowego.

${ }^{40}$ Auerbach, Werterfassung, s. 11.

${ }^{41}$ AIPN, GK, 371/874, t. 1, Drugi dzień rozprawy, 19 VII 1951 r., Zeznanie świadka Gołąbka, k. 100.

${ }^{42}$ Ibidem, Trzeci dzień rozprawy, 20 VII 1951 r., Zeznanie świadka Karoliny Marek, k. 60 .

${ }^{43}$ Ibidem, Protokół rozprawy głównej w dniu 18 VII 1951 r., k. 15-17.

${ }^{44}$ Ibidem, k. 31. 
W getcie Konrad był przede wszystkim bohaterem wielu opowieści związanych z gromadzonym przez niego majątkiem. Powszechnie uważano, że czerpie on zbyt duże korzyści z pracowników Werterfassung, by pozwolić na ich deportację, i że jest osobiście zainteresowany jak najdłuższym funkcjonowaniem tej instytucji. Wyraźnie dumny ze swojego zmysłu przedsiębiorczości Konrad otwarcie opisywał po wojnie, jak żydowscy pomocnicy wyszukiwali mu na terenie getta zabytkowe teksty liturgiczne i starodruki, które spodziewał się po wojnie sprzedać ${ }^{45}$. Duże zyski miały też przynosić Konradowi kierowane przezeń przedsiębiorstwa działające poza Werterfassung, lecz zdobywające materiały w dużej mierze z rekwizycji. Sam Konrad określał je jako „dużą liczbę wydajnych przedsiębiorstw i warsztatów”46. Jednym $z$ nich był warsztat wyrobów bakelitowych funkcjonujący w bloku szopu Többensa. $\mathrm{Z}$ tego względu w getcie panowało przekonanie, że żaden $\mathrm{z}$ funkcjonariuszy niemieckich nie odnosi ze swojego urzędu korzyści porównywalnych z tymi osiąganymi przez Konrada ${ }^{47}$. Właśnie w związku z tą działalnością w najbliższym niemieckim otoczeniu, nazywanym przez niego w zeznaniach „kołami koleżeńskimi SS”, powszechnie mówiono o nim jako o „królu getta”48.

Dochodząc tym samym bezpośrednio do wydarzeń z 23 kwietnia 1943 r. i do tego, w jaki sposób pracownicy Werterfassung zostali nakłonieni do przejścia na Umschlagplatz, trzeba jeszcze dodać, że Konrad, który wówczas obiecywał swoim pracownikom życie, już raz wcześniej słowa dotrzymał. Jak opisuje Ber Warm, we wtorek 20 kwietnia Konrad, tak jak i inni przedsiębiorcy, wezwał pracowników Werterfassung do stawienia się przed gmachem Gminy Żydowskiej, zapewniając jednocześnie, że nie grozi im wysiedlenie. Według Warma, z 4500 pracowników zgłosiło się tylko około 1500, a reszta się ukryła ${ }^{49}$. Pracownikom Werterfassung nic się tego dnia nie stało i zgodnie z zapowiedziami Konrada wszyscy powrócili bezpiecznie do domów. W czasie pobytu na placu przed gminą Konrad miał publicznie kategorycznym tonem odmówić Többensowi, mianowanemu w marcu $1943 \mathrm{r}$. przez Globocnika pełnomocnikiem do spraw przetransportowanych zakładów (Bevollmächtigter für die Verlegung der Betrieb im jüdischen Wohnbezirk Warschau), wysłania swoich pracowników do obozu pracy. W rezultacie Werterfassung umocnił swoją pozycję jako miejsca niepodlegajacego deportacji i, według szacunkowych obliczeń Bera Warma, liczba osób na Niskiej natychmiast wzrosła z 4000 do 6000, powiększając się zarówno o pracowników innych szopów, jak i tych, którzy do tej pory się ukrywali. Łapówki wręczane za zatrudnienie w urzędzie miały wówczas wzrosnąć z 500 do 5000 zł $^{50}$.

Kiedy w piątek 23 kwietnia Konrad znowu wezwał swoich pracowników, około 3000 osób zgłosiło się już dobrowolnie i, jak pisze Warm, pełni nadziei odmaszero-

\footnotetext{
${ }^{45}$ AIPN, GK, 371/874, t. 8, Oświadczenie Konrada, k. 66.

${ }^{46}$ Ibidem, k. 53.

${ }^{47}$ AŻIH, 302/188, Relacja Bera Warma, k. 2.

${ }^{48}$ AIPN, GK, 371/874, t. 8, Oświadczenie Konrada, k. 101.

${ }^{49}$ AŻIH, 302/188, Relacja Bera Warma, k. 8.

${ }^{50}$ Ibidem, k. 3.
} 
wali na Umschlagplatz ${ }^{51}$. Spośród nich tylko 500 udało się ocalić, w większości byli to drukarze i introligatorzy ${ }^{52}$. Tłumacząc swoje działania, Franz Konrad mówił po wojnie, że rozkazowi dostarczania na Umschlagplatz pracowników Werterfassung, „w tym wielu jego osobistych przyjaciół”"53, nie mógł się przeciwstawić, gdyż wydał go osobiście nowo dowodzący akcją likwidacyjną w getcie warszawskim Jürgen Stroop. Powojenne zeznania Konrada i Stroopa nie pozostawiają wątpliwości, że po przybyciu tego drugiego do Warszawy 19 kwietnia 1943 r. doszło pomiędzy nimi niemal natychmiast do otwartego konfliktu, który, jak się wydaje, był naturalną kontynuacją konfliktu kompetencji pomiędzy Globocnikiem a Stroopem. Konrad pozostał w getcie jako swego rodzaju reprezentant Globocnika i z tego względu nie opuszczał najbliższego otoczenia Stroopa przez cały okres powstania. Choć nie ma świadectw na bezpośredni wkład Konrada w zbrodnie dokonywane podczas walk, wielu świadków odnotowało jego obecność, szczególnie przy przeszukiwaniu wyciąganych z bunkrów mieszkańców getta ${ }^{54}$. Jednocześnie Konrad cały czas robił fotografie z przebiegu pacyfikacji powstania, które potem załączone zostały przez Stroopa jako materiał ilustracyjny do jego raportu. Jak sam Konrad zeznawał, miały one być dowodem na okrucieństwa popełniane podczas tłumienia powstania ${ }^{55}$.

Powodem konfliktu ze Stroopem podawanym po wojnie przez Konrada był odmienny stosunek do zgromadzonego w wyniku ciężkiej pracy Werterfassung mienia. Stroop jakoby nie był specjalnie zainteresowany jego wykorzystaniem. Choć Konrad twierdził po wojnie, że proponował wysłanie tych dóbr będącym w potrzebie mieszkańcom Niemiec, Stroop znaczną część majątku spalił. „I tak w Warszawie, obliczając bardzo skromnie, spaliło się 1000 wagonów pierzyn” - relacjonował po wojnie Konrad. Pozostałą część majątku Stroop oddał wysokim urzędnikom. Według Konrada, cztery czy pięć samochodów w ciągu jednego tygodnia bez przerwy wywoziło przedmioty ze składów w palącym się getcie. Jak zeznał Konrad, w konsekwencji „z zebranego i nagromadzonego mienia żydowskiego pozostała może tylko część literatury"56.

Sam Stroop zeznawał z kolei, że ciemne interesy Konrada wydawały mu się nie licować z postawą żołnierza niemieckiego. Ujął to następująco: „Zarówno Oberführer Frankenegg oraz oskarżony Konrad należeli od tego towarzystwa, w którym ja,

${ }^{51}$ Ibidem, k. 16 .

${ }^{52}$ AIPN, GK, 371/874, t. 1, Protokół rozprawy głównej w dniu 18 VII 1951 r., k. 25.

${ }^{53}$ Ibidem, t. 8, Oświadczenie Konrada, k. 73.

${ }^{54}$ Leon Najberg, Fragment z pamiętnika gruzowca [w:] Dokumenty i materiaty do dziejów Żydów w Polsce, t. 2: Akcje i wysiedlenia, red. Józef Kermisz, Łódź: Centralna Żydowska Komisja Historyczna, 1946, s. 336.

${ }^{55}$ AIPN, GK, 371/874, t. 1, Protokół rozprawy głównej w dniu 18 VII 1951 r., k. 44.2 i 4 X 1948 r. Konrad przesłuchiwany był przez sędziego apelacyjnego śledczego Józefa Skorżyńskiego, członka Głównej Komisji Badania Zbrodni Niemieckich w Polsce. W zeznaniu twierdził, że fotografiami robionymi podczas powstania chciał obciążyć Stroopa (ibidem, t. 8, k. 180).

${ }^{56}$ AIPN, GK, 371/874, t. 8, Oświadczenie Konrada, k. 99. 
jako żołnierz, nie chciałem brać udziału"57. Później dodał, że w jego przekonaniu „ci ludzie lepiej by wykonywali swój urząd, jeśliby byli tam, gdzie należało, bo była wojna"58. W rezultacie miał osobiście interweniować u Himmlera, żądając wysłania Konrada na front wschodni ${ }^{59}$. Aby zapobiec dalszym konfliktom, kierownictwo Osti usunęło Konrada z getta i powierzyło mu zadanie skontrolowania warunków panujących w ówczesnym obozie jeńców wojennych we Włodawie, który miano przekształcić w obóz pracy SS. Następnie wykorzystano Konrada, by ocenił możliwości zbierania przedmiotów wartościowych podczas likwidacji getta w Białymstoku w sierpniu 1943 r. W październiku tego roku Konrad był zaś w Łodzi, gdzie miał na polecenie Globocnika oszacować liczbę pociągów potrzebnych do przesiedlenia getta łódzkiego do Lublina. Sam Konrad stwierdził, że sabotował to polecenie, gdyż podał w raporcie, iż transport taki jest niewykonalny. Jednocześnie po upadku powstania w getcie warszawskim Konrad kontynuował swoją działalność $\mathrm{w}$ Warszawie, zajmując się wydostawaniem $\mathrm{z}$ ruin getta maszyn potrzebnych dla Osti. Zaangażował się też $\mathrm{w}$ organizowanie warsztatów w budowanym wówczas KL Warschau ${ }^{60}$. W listopadzie 1943 r., po Aktion „Erntefest” - masowej egzekucji wszystkich Żydów pracujących w obozach pracy w Trawnikach, Poniatowej, na Majdanku i w innych obozach w dystrykcie lubelskim - działalność Osti i tym samym praca Konrada w okupowanej Polsce dobiegła końca.

13 grudnia 1943 r. Franz Konrad otrzymał rozkaz stawienia się w Berlinie, gdzie powierzono mu objęcie bardzo atrakcyjnej funkcji kierownika administracyjnego na zamku SS w Fischorn pod Salzburgiem. Tam przebywał aż do momentu swojego aresztowania 21 sierpnia $1945 \mathrm{r}$. Z dokumentów przekazanych przez armię amerykańską Głównej Komisji Badania Zbrodni Niemieckich w Polsce wynika, że w momencie aresztowania Konrada w centrum jej zainteresowania były nie tyle popełnione przez niego zbrodnie wojenne, ile wciąż znajdujący w jego posiadaniu majątek, zarówno ten wywieziony z Warszawy, jak i zgromadzony już podczas jego pobytu w Fischorn. Zaraz po aresztowaniu Konrad miał przekazać władzom amerykańskim listy Hitlera i Ewy Braun, garnitur, który miał na sobie Hitler w dniu zamachu na niego 20 lipca 1944 r., i liczne zdjęcia ${ }^{61}$. Konrad był początkowo więziony w Zell Am See, 13 września 1945 r. przekazano go do Glasenbach koło Salzburga, stamtąd 5 czerwca do więzienia w Regensburgu. Tam przesłuchiwano go po raz kolejny w sprawie pieniędzy, listów i przedmiotów osobistych Hitlera, o których Konrad zapewniał, że je spalił. Przetrzymanie go w celi przez 11 dni o chlebie i wodzie nie dało według dokumentów amerykańskich żadnych rezultatów ${ }^{62}$. Podejrzewając jednak, że zna on miejsce ukrycia znacznie większej liczby wartościowych

\footnotetext{
${ }^{57}$ Ibidem, t. 1, Drugi dzień rozprawy, 19 VII 1951 r., k. 35.

${ }^{58}$ Ibidem, k. 73.

${ }^{59}$ Ibidem, Protokół rozprawy głównej w dniu 18 VII 1951 r., k. 67.

${ }^{60}$ AIPN, GK, 371/874, t. 8, Oświadczenie Konrada, k. 104-105.

${ }^{61}$ Ibidem, t. 3, Counter Intelligence Corps, Oddział V, Nota do dowódcy oddziału. Temat: Conrad, Franz, k. 83.

${ }^{62}$ Ibidem, k. 83.
} 
przedmiotów, Amerykanie umieścili w celi sąsiadującej z Konradem agenta, którego celem było zaprzyjaźnienie się ze skazanym i wydobycie od niego stosownych informacji ${ }^{63}$. Akcja amerykańska została przerwana przez polski wniosek ekstradycyjny. 11 maja 1946 r. rząd polski wystąpił o ekstradycję Franza Konrada, znanego pod pseudonimem „Ghetto Konrad”, jako „odpowiedzialnego za masowe zabójstwo 60000 Żydów w Getcie Warszawskm”64. 4 września 1946 r. Konrad został wysłany do Polski. Tego samego dnia jednak udało mu się uciec z transportu. Według tajnego raportu kontrwywiadu armii amerykańskiej, Konrad uciekł wraz z czterema innymi więźniami przez otwór w podłodze pociągu. Jak sam twierdził: „wolność czekająca za dziurą w podłodze okazała się zbyt dużą pokusą" ${ }^{\text {"25 }}$. Został ujęty 26 września, kiedy szukał schronienia od adresem podanym mu przez opisywanego już podstawionego w więzieniu agenta. Po ponownym aresztowaniu Konrada władze amerykańskie odrzuciły jego propozycję współpracy i natychmiast, tym razem bez problemów, deportowano go do Polski66.

W Polsce Konrad sądzony był w jednym procesie ze swoim przeciwnikiem z getta - Jürgenem Stroopem. Proces Stroopa miał być ostatnim, po procesach członków załogi obozu w Majdanku, gauleitera Kraju Warty Arhtura Greisera, komendanta obozu w Płaszowie Amona Götha, gubernatora dystryktu warszawskiego Ludwiga Fischera, komendanta KL Auschwitz Rudolfa Hössa, gauleitera Gdańska Alberta Forstera i szefa rządu Generalnego Gubernatorstwa Josefa Bühlera, z serii wielkich procesów zbrodniarzy hitlerowskich. Po ujęciu Stroopa planowano „małą Norymberge”, w której obok kata getta warszawskiego sądzeni mieli być Erich von dem Bach-Zelewski, dowodzący pacyfikacją powstania warszawskiego, czy Johannes Blaskowitz, dowodzący 6. Armią podczas wojny z Polską we wrześniu 1939 r. ${ }^{67}$ Tymczasem w praktyce jedynym, którego udało się osądzić oprócz Stroopa, był, prawdopodobnie z braku lepszych kandydatów, Franz Konrad. Nie udało się ujać szefa sztabu akcji „Reinhardt” Hermanna Höflego, którego chciano osądzić podczas tej samej rozprawy - jego sprawa została wyłączona. O tym, że Konrad nie był nigdy w centrum zainteresowania władz polskich, świadczyć może to, że jeszcze na początku 1948 r. w korespondencji wewnętrznej związanej z przygotowywaniem procesu występuje on jako Hans Conrad $^{68}$. Ze znajdujących się w archiwum IPN stenogramów rozprawy przed Sądem Wojewódzkim w Warszawie w dniach 18-24 lipca 1951 r. wynika niezbicie, że to na Stroopie skupiona była cała uwaga. W akcie oskarżenia stwierdzono, że Konrad „jako niemiecki urzędnik administracyjny dla rekwizycji mienia pożydowskiego, a następnie kierownik urzędu «Werterfassung» w getto warszawskim brał udział w masowych zabójstwach i prześladowaniu ludności żydowskiej w getto warszawskim i rabunku

\footnotetext{
${ }^{63}$ Ibidem.

${ }^{64}$ AIPN, GK, 371/874, t. 3, Wniosek ekstradycyjny, k. 73.

${ }^{65}$ Ibidem, Nota do dowódcy Oddziału V, k. 84.

${ }^{66}$ Ibidem, k. 84.

${ }^{67}$ Hirsz Wasser, Proces Stroopa powinien się odbyć jak najszybciej, „Nasze Słowo” 1949,
} nr 4, s. 2.

${ }^{68}$ AIPN, GK, 317/874, t. 3, Dokument z 28 II 1948 r., k. 8. 
ich mienia na rzecz Rzeszy Niemieckiej i własnej korzyści” ${ }^{69}$, niemniej w porównaniu ze stłumieniem powstania w getcie działalność Konrada wydawała się mieć zarówno dla świadków, jak i dla prokuratorów marginalne znaczenie. Jak pisałam, prokuraturze nie udało się niezbicie udowodnić bezpośredniego udziału Konrada w mordowaniu Żydów, a świadkowie więcej miejsca niż zbrodniom poświęcali jego pasji filatelistycznej. Jak podsumował w mowie końcowej obrońca Konrada:

Sam fakt, iż w toku niniejszego ociekającego krwią i łzami procesu była mowa o znaczkach pocztowych, robił jakieś niesamowite, makabryczne wrażenie. Ten ogrom zbrodni, setki tysięcy pomordowanych, płonące domy, skaczące z balkonów kobiety z dziećmi na ręku i... znaczki pocztowe [...]. Podczas gdy jego koledzy z SS zajmowali się w tymże czasie zbieraniem główek dziecięcych, rozbijanych dla zabawy o mur - on zbierał znaczki ${ }^{70}$.

Obrona Konrada opierała się więc na podkreśleniu jego nikłej roli w zestawieniu z ogromem odpowiedzialności Stroopa i innych hitlerowców, których uniewinniono lub skazano na niskie kary w procesach norymberskich. Prokuratura $\mathrm{z}$ kolei ograniczała się głównie do ogólnych wystąpień o podłożu politycznym, mających dowieść, cytując mowę prokuratora Jana Ruska: „odpowiedzialności wielkiego kapitału niemieckiego i związanego z nim kapitału zachodniego za politykę grabieży mienia żydowskiego i za bezpośrednie mordy dokonywane na Żydach i innych narodach w krajach okupowanych" ${ }^{\text {"1 }} 24$ lipca „Życie Warszawy” donosiło: „Oskarżający Konrada prokurator J[an] Rusek przypomniał, że zburzenie części Warszawy i rzeź tysięcy obywateli polskich narodowości żydowskiej były uplanowane przez SS i Wehrmacht - organizacje ściśle związanez kapitałem monopolistycznym niemieckim i anglo-amerykańskim"72. Oskarżony Konrad twierdził, że jego rola ograniczała się do pracy administracyjnej i podkreślał swoje związki z mieszkańcami $\mathrm{w}$ gettach oraz udział w ratowaniu wielu $\mathrm{z}$ nich ${ }^{73}$.

Decyzją sądu zarówno Konrad, jak i Stroop zostali skazani na karę śmierci. Jak napisano w uzasadnieniu wyroku, Konrad odpowiadał „za udział w planowym ludobójstwie, udział świadomy i przemyślany, do którego skłoniły go w równej mierze jego poglądy polityczne, jak idąca z nimi w parze nieokiełznana chęć zysku""74. Od wyroku obrońcy Konrada bezskutecznie się odwoływali. Po podtrzymaniu przez sąd wyroku 14 grudnia 1951 r. jego adwokat mecenas Jan Palatyński napisał prośbę o ułaskawienie do prezydenta Bolesława Bieruta. Palatyński wnosił, że sąd „nie dostarczył dowodów bestialstw czy okrucieństw, mordów czy rozkazów

${ }^{69}$ Ibidem, t. 1, Akt oskarżenia, 5 VII 1951 r., k. 3.

${ }^{70}$ Ibidem, t. 2, Przemówienie obrońcy oskarżonego Konrada adwokata Jana Palatyńskiego, k. 8 .

${ }^{71}$ Ibidem, Mowa prokuratora Jana Ruska, k. 1.

72 „Życie Warszawy”, 24 VII 1951, s. 2.

${ }^{73}$ AIPN, GK, 371/874, t. 2, Czwarty dzień rozprawy, 23 VII 1951 r., k. 5.

${ }^{74}$ Ibidem, k. 22. 
mordów, których by się oskarżony dopuszczał osobiście”. Powoływał się też na zasadę indywidualizacji winy i kary ${ }^{75}$. List do Bieruta z prośbą o ułaskawienie napisał również sam Konrad. Podkreślał w nim pracę dla dobra Polski, jaką wykonał po wojnie. Pisał: „Podczas mojego pięcioletniego pobytu jako więzień w Polsce starałem się wszelkimi siłami moją pracą przyczynić się do odbudowy tego kraju. Pracowałem z całą sumiennością od 1 kwietnia 1948 r. w Drukarni Mokotów aż do dnia rozprawy w dniu 18 lipca 1951 r., gdzie dorobiłem się funkcji maszynisty"76. Wreszcie, z prośbą do Bieruta zgłosiła się też żona Konrada Agnes. W dramatycznym liście, tłumaczonym wyraźnie przez kogoś, kto językiem polskim się na co dzień nie posługiwał, pisała:

Dowiadywałam teraz radio a gazetami, że mój mąż został skazany na śmierć dnia 23.7.1951 r. w Warszawie razem z generałem zbrojnego SS Stroop. $\mathrm{O}$ ile mi wiadomo, mój mąż nie zawinił podczas swego pobytu w Warszawie a osobno podczas swego komendowania do Ghetto w Warszawie żadne niesprawiedliwości. Jeśli mój mąż jednak został oskarżony a skazany z racji formalnego przewinienia, to jest $\mathrm{z}$ racji przynależności do zbrojnego SS, jako administracyjny oficer, proszę, aby wielmożny pan prezydent łaskawie zważał, że mój małżonek odpokutował już bardzo zbyt długim czasem więzienia a że wyrok wyznaczony ku niemu jest zbyt srogi.

Mój mąż jest ojcem trzech dzieci, z których dwa są nieopatrzone. Jest mi znane, że troska o los zupełnie niewinnej rodziny a zwłaszcza dzieci czyni mu własny los ku najokrutniejszej nędze bo był zawsze wzorowy ojciec rodziny, któremu była swa rodzina ponad wszystko.

Wykluczam zupełnie, że Franciszek Konrad jest sposobnym jakiegokolwiek czynu karygodnego, oprócz może wzmiankowanego przewinienia formalnego. Przeciwnie, mogłam wnosić z jego dawniejszych opowiadań, że głos jego serca nakazywał mu w niezliczonych przypadkach, z którymi się stykał, aby łagodził lub odwrócił widoczną niesprawiedliwość, z zaniedbaniem bezpieczności swojej osoby a przeciw rozkazowi inaczej brzmiącemu. Taki karakter zdradza głębokie ludskie uczucie.

29 lutego 1952 r. Sąd Wojewódzki w Warszawie został poinformowany, że prezydent Rzeczypospolitej Polskiej nie skorzystał z przysługującego mu prawa łaski w stosunku do Franza Konrada, syna Floriana. Konrad został powieszony 6 marca $1952 \mathrm{r}$.

Silne upolitycznienie powojennego procesu i marginalizacja jego sprawy przy koncentracji na Jürgenie Stroopie sprawia, że ocena postępowania Konrada jest dzisiaj niemożliwa. Trudno powiedzieć, do jakiego stopnia był on tylko chciwym urzędnikiem, który nieomal przez przypadek znalazł się w Warszawie, a do jakiego świadomym graczem i ważnym ogniwem Aktion „Reinhardt”. Prawda jak zawsze leży gdzieś pośrodku. Przybliżenie jego sylwetki jest jednak niezwykle ważne dla

\footnotetext{
${ }^{75}$ AIPN, GK, 371/874, t. 2, k. 193.

${ }^{76}$ Ibidem, k. 221.
} 
badań nad praktyką wdrażania polityki zagłady Żydów w Generalnym Gubernatorstwie i dla wciąż nie do końca poznanej historii getta warszawskiego z okresu po wielkiej akcji.

\title{
Słowa kluczowe
}

Franz Konrad, getto warszawskie, akcja „Reinhardt”, procesy zbrodniarzy hitlerowskich

\begin{abstract}
Franz Konrad, the head of the Werterfassung - and institution which seized and secured the property the deported Jews left behind in the Warsaw ghetto - was one of the key figures in the ghetto after the Great Deportation Action. Up to 4,000 ghetto inhabitants worked in the Werterfassung collecting, sorting and transporting looted property. Even though the institution was beieved to be a workplace theat offered relative security, almost all of its employees were deported in April 1943. The article, based on the ghetto inhabitants' memoirs, stenographic records of Konrad's trial and his testimonies given right after the war, shows the role he and the property confiscation played both in the everyday life of the ghetto as in the carrying out of Aktion Reinhardt.
\end{abstract}

\section{Key words}

Franz Konrad, Warsaw ghetto, Aktion Reinhardt, Nazi war criminals’ trials 